\title{
Effect of Treatment of Callistephus chinensis (L.) Ness. Plants by Ivin at Growth and Decorative Parameters in Conditions of Industrial City
}

\author{
Valentina Bessonova, Olga Ivanchenko*, Svetlana Volodarets \\ Dnipro State Agrarian and Economic University, 25 Serhii Yefremov Str., Dnipro, Ukraine, 49600 \\ spg.dsaeu@gmail.com, 'ivanchenko_78@ukr.net, svetlana_volodarez@i.ua
}

\begin{abstract}
Keywords: industrial city, Dnipro, Callistephus chinensis (L.) Ness., cytokinins, Ivin, morphological indexes, chlorophyll
\end{abstract}

\begin{abstract}
The effect of the new growth stimulator with the cytokinin nature Ivin was investigated at the parameters of growth, blooming and chlorophyll concentration of the leaves of Callistephus chinensis (L.) Ness. plants. The researched plants grow under the impact of industrial and exhaust fumes. The intensification of the growth processes of the treatment plants in comparison with untreated was established. The processed specimens enhance height, the number of side shoots, quantity of the leaves and their area as well as the area of the total assimilation plants surface with increasing of the vegetative mass of the plants accordingly. At the same time, the number of inflorescences and their average diameter increase. There was no significant difference in essential influence of the biostimulant upon the plants of Callistephus chinensis between breeds "Viktoria Sharlachovaya" and "Strausovo pero Rubinovaya" with the exception of some variables (total assimilation surface). The concentration of chlorophyll in leaves of Callistephus chinensis plants increases under spraying by Ivin. The rising occurs originally after spraying seedlings due to chlorophyll, after the third treatment (flower-bud formation) - due to both forms of chlorophylls was established, as well as the breed specific reaction of plants was determined. The novelty of this work consists in the investigation of the influencing the growth stimulator on the development of the ornamental flower plants in the conditions of environmental pollution. The treatment of this preparation is appropriate for stimulation of growth and intensity of bloom of the ornamental flower plants of urban territories.
\end{abstract}

\section{Introduction}

In the conditions of economic growth, intensive development of industry, enhancing quantity of the vehicles all over the world, there is a tendency of the increasing the level of air pollution, which is the subject of research by many scientists [1-4]. The green plantings of recreation parks, mini-parks, forest and meadow parks, sanitary protection zones etc. play an incredible role in the improvement of urban environment. In the urban conditions they are considered as the very effective and economically advantageous approaches of improving the comfort and quality of the habitant's life.

The flowering gardening that formulated the esthetic view of gardens and parks is regarded as one of the effective methods of decoration the objects of landscape architecture [5-7]. The planning nodes of the park - parterre squares, entrances, recreation areas are designed with the help of flower beds, creates accents that focus attention, direct movement and complete the artistic design of park compositions [8]. Ornamental flower plants, while implemented esthetic function in urban parks, are facing the negative influence by nearby environment mainly of anthropogenic character.

The negative tendencies such as the total decline of ecological environment, decreasing the persistence of greenery plantations due to impact of fumes of industrial enterprises and vehicles, increasing recreation pressure, enhancing the built-up territories and areas with pavage, using the composites to preventing the glace-ice on the pavements, reduction of green areas et al. are presented in parks of big industrial cities [9]. It should be noted that the majority of parks within the 
city of Dnipro are located close to the automobile roads with the high traffic intensity as well as under the impact of emissions of metallurgical enterprises and thermal electric power station [10].

In such growing conditions the regulation of physiological plant processes that determining the growth, development and thus ornamentations is an urgent task. The using of plants biostimulants - the group of products contained natural and synthetic hormones, encouraging the more active growth, increasing the decorative effect of plants poses the perspective decision in this problem. The adequate materials about theoretical and practical aspects of studying biostimulants due to ornamental flower plants is presented in the literature, however mostly gibberellins and retardants are used [11-22 et al.]. The data on the effect of substances of cytokinin nature, especial new biostimulants, is shown considerably less [13, 20, 23-27].

The various new substances with physiological activity that used for growing the ornamental plants $[28,29]$ as well as flowers $[16,30,31]$ have been synthesized recently. Many authors have noted the positive effect of synthesized phytohormones of growing plants under salinization conditions $[32,33]$, pollution with heavy metals $[23,24,34-36]$. The scientific findings dealt with the impact of Ivin biostimulant to the development of ornamental flower plants either in the conditions of pure zone or in the polluted environment are almost failed.

The aim of this article is the studying the influence of the treatment with biostimulant of cytokinin nature (Ivin) at the growing processes, generative development and state of the assimilation apparatus of annual ornamental plant Callistephus chinensis in the anthropogenic growing conditions.

\section{Materials and Methods}

The object of the investigation is presented by the plants two widely used in the greenery urban management breeds "Viktoria Sharlachovaya" and "Strausovo pero Rubinovaya" of china aster (Callistephus chinensis (L.) Ness.).

The seedlings of Callistephus chinensis were planted out in the age of 30 days at the residential area, which is located near the Park of Memory and Conciliation of Dnipro city. Dnipro situates in the Eastern part of Ukraine at the $48^{\circ} 47^{\prime}$ northern latitude, $35^{\circ} 00^{\prime}$ east longitude and an altitude of 86 m.a.s.1. The site places in the Chechelov district of the city in the distance of 2,3 km from the West industrial complex that included metallurgical plant with fulfill production cycle, pipe-rolling, machine building, electric locomotive building, metal constructions, metal chemical, harvester building, instrument engineering and other plants. The experimental site situated not far from the automobile road with a high intensity of movement of cars and trucks (av. S. Nigoyana), which is a source of air pollution with heavy metal and gaseous pollutants. The rate of traffic flow on this street is 48000 vehicles per day. The gaseous pollutants and aerosols of heavy metal which dominated at this site are the major air contaminators. The air quality monitoring station places in $2 \mathrm{~km}$ from the plot, where the plants have been growing (av. S. Nigoyana, 77). The average daily concentration of $\mathrm{O}_{3}, \mathrm{NO}_{2}, \mathrm{SO}_{2}$ amounted to 0,$101 ; 0,060$ and $0,120 \mathrm{mg} / \mathrm{m}^{3}$ in May; 0,$339 ; 0,155$ and $0,138 \mathrm{mg} / \mathrm{m}^{3}-$ in June; 0,$300 ; 0,164$ and $0,056 \mathrm{mg} / \mathrm{m}^{3}$ in July; 0,$312 ; 0,156$ and $0,130 \mathrm{mg} / \mathrm{m}^{3}-$ in August. The average daily maximum permissible concentration (MPC) of $\mathrm{O}_{3}, \mathrm{NO}_{2}, \mathrm{SO}_{2}$ equals 0,$030 ; 0,040$ and $0,050 \mathrm{mg} / \mathrm{m}^{3}$.

During growth of plants we adhere to the uniformity of the agrotechnical background and optimal conditions of mineral nutrition. Two plots with the square $15 \mathrm{~m}^{2}$ were made during the investigation. The plants on the fist plot were treated by Ivin while from the other - by distilled water. The exploring plots with treated and untreated plants have situated near each other, that's why all factors of the ambient environment were equaled apart from the treatment of plants by biostimulant. The plot where plants have grown characterized with horizontal terrain. We have chosen the plants for analysis by random (accidental) sampling.

Ivin of the "Agrobiotech" trademark (Ukraine) (Technical Specifications of Ukraine 24.203563790-012-2002) was used as biostimulant. The active substance of Ivin is 2,6dimethylpyridine-1-oxide. The preparation is produced in the form of colorless alcohol-water solution and has a cytokinin activity [37]. According to the Ukrainian sanitation rules Ivin belongs 
to the low-toxic substances [38]. LD50 for mice amounts $1390 \mathrm{mg} / \mathrm{kg}$. Its molecular mass equals $123.14 \mathrm{~g} / \mathrm{mole}$, the molecular formula is $\mathrm{C}_{7} \mathrm{H}_{9} \mathrm{NO}$. The biostimulant is implicated in the growing technology of all vegetable and orchard-truck crops for pre-sowing seed treatments and foliar spraying during vegetative term upon the recommendations of producer. This preparation provides the accelerated division of cells, decreases the illness frequency among plants, the phytotoxicity of pesticides, provides the formation of the extensive root system and sexual specialization of flowers, improves the quality of growing production, plant resistance to environmental and anthropogenic stresses, enhances the field germination capacity of seeds. The morning hours before 10-11 a.m. and the evening hours after 17 p.m. are the most effective to the treatment plants by the preparation. We spray the plants with standard preparation after the instruction of producer in the phase of seedlings (10/V), active growth plants (in 30 days after the first spraying (10/VI)) and at the beginning of flower-bud formation (19/VII). The control plants in the same term were treated with distilled water. We have measured the size of the seedlings in 10 and 20 days after the first treatment and in 10,20 and 30 days after the second treatment. The number of the first range shoots was counted in 30 days after the second treatment as well as in 20 and 30 days after the third one. We have counted the quantity of inflorescences during the starting of the blossoming (5/VIII) and the massive plants blossoming (15/VIII and 30/VIII). The numbers of leaves were amounted in 10 days after the first treatment and further at intervals in 10 days. We conducted the last counting up the number of leaves during the period of termination the formation of the side shoots and new leaves. We have conducted the measure of the plant height, calculated the number of leaves, flowers, ranged the diameter of the latter in $50^{\text {th }}$ frequency $(n=50)$. The weight of vegetative underground part and the area of the leaves were estimated by the gravimetric method in $5^{\text {th }}$ frequency $(n=5)$ [39]. The pigment content was founded in the extract of $96 \%$ ethanol by the spectrophotometer-200 in the $4^{\text {th }}$ frequency $(n=4)$. All calculations were obtained with the equations Wintermans, De Mots [40].

The results are shown by the means \pm mean absolute error (MAE). The differences among varieties we analyzed with the Student's t-test $(\mathrm{p}<0.05)$.

\section{Results}

The spraying of Callistephus chinensis plants with the biostimulant of cytokinin nature Ivin enhances the growth process of plants objects. The height of plants increases in comparison with untreated specimens in both investigated breeds. The effect of positive impact of biostimulants for this measure in breed "Viktoria Sharlachovaya" has much in common with "Strausovo Pero" (fig. 1A). Thus, the height of stem in breed "Viktoria Sharlachovaya" enhances on $32,96 \%$ related to the control at the start of the experiment, in the following stages of observations (10/VI, 20/VI and $9 / \mathrm{VII}$ ) the effect was maintained at the level of 30,$06 ; 35,23$ and $26,59 \%$ above control (fig. 1B) The similar tendency was observed to the breed 'Strausovo pero Rubinovaya'. 


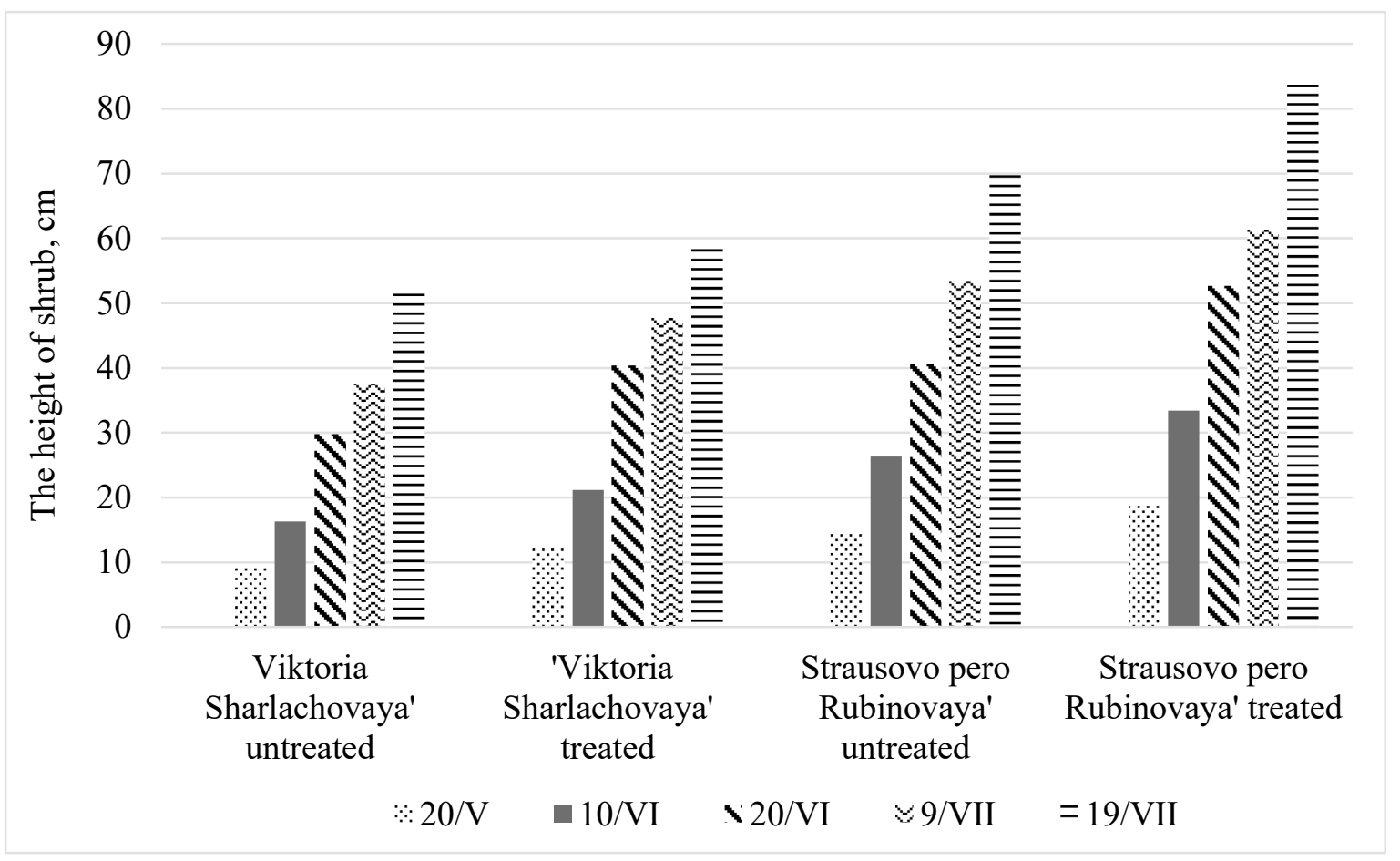

A

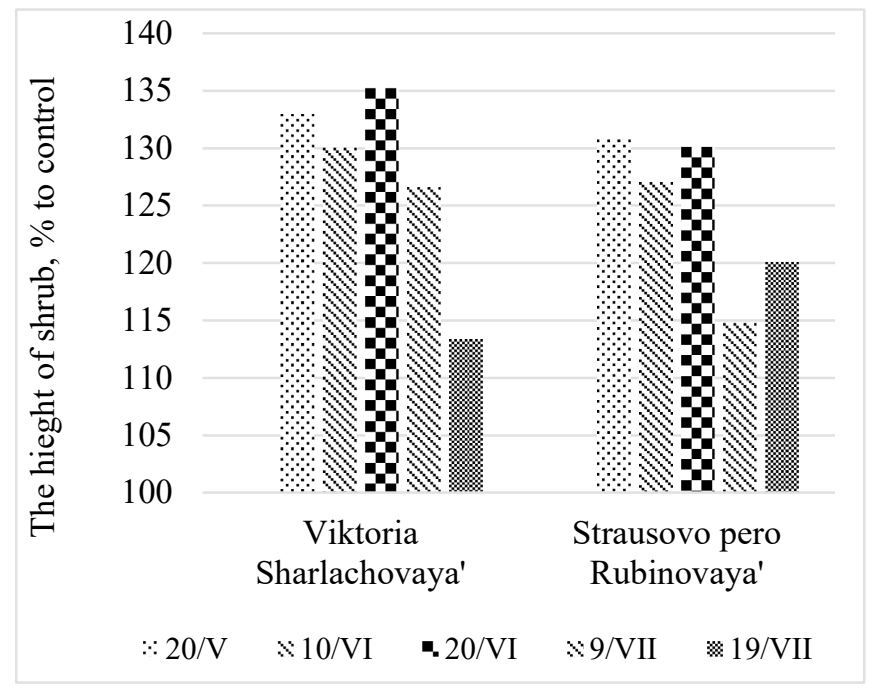

B

Figure 1. The impact of the treatment of plants Callistephus chinensis by Ivin to the height of the shrub (A - in absolute figures, $B-$ in $\%$ to control) $(n=50)$

The treatment of Callistephus chinensis plants by Ivin leads to the enhancement of the number of side shoots. So, in the period coincides with the mass blossom (20/VIII) their quantity in the breed 'Viktoria Sharlachovaya' in plants of treated variant in relation to control works out $140,32 \%$. In the breed 'Strausovo pero Rubinovaya' - 135, $71 \%$ (table 1). It is estimated the increasing positive effect of the biostimulant during the vegetation. The differences in the changes of the number side shoots under action of the biostimulant are not too big. 
Table 1. The impact of treatment of Callistephus chinensis plants by Ivin to the number of the shoots of the first range and inflorescences, pcs $(n=50)$

\begin{tabular}{|c|c|c|c|c|c|c|}
\hline \multirow{2}{*}{ Variant } & \multicolumn{7}{|c|}{ Number of stems of the first range } & \multicolumn{3}{c|}{$\begin{array}{c}\text { The number of inflorescences } \\
\text { at the plant }\end{array}$} \\
\cline { 2 - 7 } & $11 /$ VII & $10 /$ VIII & 20/VIII & 5/VIII & $15 /$ VIII & $30 /$ VIII \\
\hline \multicolumn{7}{|c|}{ The breed 'Viktoria Sharlachovaya' } \\
\hline Untreated & $3,5 \pm 0,20$ & $5,3 \pm 0,25$ & $6,2 \pm 0,62$ & $0,5 \pm 0,02$ & $2,7 \pm 0,14$ & $4,2 \pm 0,12$ \\
\hline Treated & $4,3 \pm 0,11$ & $7,2 \pm 0,30$ & $8,7 \pm 0,84$ & $0,7 \pm 0,08$ & $3,5 \pm 0,10$ & $7,1 \pm 0,15$ \\
\hline $\mathrm{t}$ & 3,51 & 4,87 & 2,39 & 2,43 & 4,65 & 15,10 \\
\hline \% to control & 122,80 & 135,84 & 140,32 & 140,00 & 129,63 & 169,04 \\
\hline \multicolumn{7}{|c|}{ The breed 'Strausovo pero Rubinovaya' } \\
\hline Untreated & $4,0 \pm 0,30$ & $6,1 \pm 0,42$ & $7,0 \pm 0,80$ & $0,2 \pm 0,05$ & $3,3 \pm 0,12$ & $6,2 \pm 0,31$ \\
\hline Treated & $4,8 \pm 0,15$ & $7,9 \pm 0,31$ & $9,5 \pm 0,62$ & $0,4 \pm 0,03$ & $5,0 \pm 0,16$ & $9,0 \pm 0,60$ \\
\hline t & 2,42 & 3,49 & 2,47 & 3,45 & 8,50 & 4,15 \\
\hline \% to control & 120,00 & 129,50 & 135,71 & 200,00 & 151,51 & 145,16 \\
\hline
\end{tabular}

The quantity of leaves of the plants rises under the influence of biostimulant, however the level of enhancing their quantity is less significant than shoots (table 2). This may testify about the formation of the less number of leaves at the appeared shoots in the experimental variant. In the mentioned periods of measurements the level of the favorable effect of this parameter in the plants of both breeds is estimated as related to data.

Table 2. The impact of the treatment of plants by Ivin at the number of leaves at the plant, pcs $(\mathrm{n}=50)$

\begin{tabular}{|c|c|c|c|c|c|}
\hline Variant & 20/VI & 11/VII & 19/VII & $30 /$ II & $20 /$ III \\
\hline \multicolumn{7}{|c|}{ The breed 'Viktoria Sharlachovaya' } \\
\hline Untreated & $18,3 \pm 0,51$ & $25,2 \pm 0,80$ & $30,4 \pm 1,18$ & $45,8 \pm 2,10$ & $57,2 \pm 0,82$ \\
\hline Treated & $21,0 \pm 0,60$ & $29,1 \pm 1,04$ & $40,4 \pm 1,27$ & $56,1 \pm 1,62$ & $73,9 \pm 2,42$ \\
\hline \% to control & 114,75 & 115,47 & 132,89 & 122,48 & 129,19 \\
\hline $\mathrm{t}$ & 3,46 & 2,97 & 5,78 & 3,88 & 6,55 \\
\hline \multicolumn{7}{|c|}{ The breed 'Strausovo pero Rubinovaya' } \\
\hline Untreated & $25,7 \pm 0,42$ & $40,0 \pm 1,02$ & $49,7 \pm 1,24$ & $68,0 \pm 2,04$ & $80,3 \pm 2,1$ \\
\hline Treated & $28,4 \pm 0,56$ & $45,5 \pm 0,50$ & $66,8 \pm 2,01$ & $88,3 \pm 1,30$ & $99,2 \pm 1,10$ \\
\hline$\%$ to control & 110,50 & 113,75 & 134,40 & 114,28 & 129,85 \\
\hline $\mathrm{t}$ & 3,85 & 4,86 & 3,00 & 7,24 & 7,97 \\
\hline
\end{tabular}

The stimulated action of the treatment with the synthetic biostimulant of cytokinin type at the accumulation of biomass by the underground part of the plant in the breed 'Strausovo pero Rubinovaya' develops some essential as compared with the breed 'Viktoria Sharlachovaya' (table 3 ). Thus, this parameter of the plants from the breed 'Viktoria Sharlachovaya' enhances the control at $52,36 \%$, though in the breed 'Strausovo pero Rubinovaya' goes up by $63,46 \%$ in comparison with untreated. The average area of the leaf blade grows up under the influence of spraying plants by Ivin, to a greater extent in the plants of the breed 'Viktoria Sharlachovaya' (table 3). The difference between the treated and untreated plants for this breed works out $27,06 \%$, just as for the breed 'Strausovo pero Rubinovaya' the distinguishing is less $-15,57 \%$, however it is valid statistically at the $95 \%$ level of probability. The dimensions of the total assimilation surface on the plant increase more significantly. The excess of control in the blooming phase at the breeds 'Viktoria Sharlachovaya' and 'Strausovo pero Rubinovaya' works out 45,81 and 27,72\% respectively relative to the untreated plants objects. 
Table 3. The impact of treatment of Callistephus chinensis plants by Ivin to the area of the leaf blade, total of the assimilation surface, the dry mass of the aboveground part and diameter of the inflorescences (10/VIII)

\begin{tabular}{|c|c|c|c|c|}
\hline The breed & Untreated & Treated & $\%$ to control & $\mathrm{t}$ \\
\hline \multicolumn{6}{|c|}{ The square of the leaf blade, $\mathrm{cm}^{2}(\mathrm{n}=5)$} \\
\hline 'Viktoria Sharlachovaya' & $24,20 \pm 1,15$ & $30,75 \pm 1,35$ & 127,06 & 3,70 \\
\hline 'Strausovo pero Rubinovaya' & $25,81 \pm 1,02$ & $29,83 \pm 1,17$ & 115,57 & 2,59 \\
\hline \multicolumn{6}{|c|}{ The total square of the assimilation surface, $\mathrm{cm}^{2}$ to 1 plant $(\mathrm{n}=5)$} \\
\hline 'Viktoria Sharlachovaya' & $442,86 \pm 19,31$ & $645,75 \pm 27,14$ & 145,81 & 6,09 \\
\hline 'Strausovo pero Rubinovaya' & $663,32 \pm 24,15$ & $847,17 \pm 35,35$ & 127,72 & 4,29 \\
\hline \multicolumn{6}{|c|}{ The dry vegetative plant mass, $\mathrm{g}(\mathrm{n}=5)$} \\
\hline 'Viktoria Sharlachovaya' & $120,5 \pm 10,20$ & $183,60 \pm 9,30$ & 152,36 & 4,57 \\
\hline 'Strausovo pero Rubinovaya' & $139,39 \pm 12,14$ & $227,86 \pm 15,71$ & 163,46 & 4,45 \\
\hline \multicolumn{6}{|c|}{ Diameter of inflorescences, cm (n=50) } \\
\hline 'Viktoria Sharlachovaya' & $9,42 \pm 0,32$ & $10,48 \pm 0,22$ & 111,25 & 2,73 \\
\hline 'Strausovo pero Rubinovaya' & $12,14 \pm 0,27$ & $14,74 \pm 0,34$ & 121,42 & 5,99 \\
\hline
\end{tabular}

Under the influence of Ivin the number of shoots increases simultaneously with quantity of inflorescences. Thus, their number rises the control for $40 \%$ in the plants Callistephus chinensis of the breed 'Viktoria Sharlachovaya' treated by the biostimulant on 5/VIII, otherwise in breed 'Strausovo pero Rubinovaya' - on 100,0 \%. In the subsequent terms of the experiment (15/VIII and $30 / \mathrm{VIII})$ these figures in the breed 'Strausovo pero Rubinovaya' were slightly less. The diameter of the inflorescence increased statistically significantly, moreover, notably in slightly bigger level in the breed 'Strausovo pero Rubinovaya' (table 3).

The results of the treatment of Callistephus chinensis plants on the green pigment concentration in the leaves are shown in the table 4. Only the concentration of chlorophyll $a$ increase in the leaves of breed 'Viktoria Sharlachovaya' after the first spraying by Ivin, therefore the ratio of chlorophylls a/b becomes bigger, than in leaves of control variant (table 4 ). The sum of chlorophylls $a+b$ is higher in the variant with treatment by biostimulant. Similar changes in the chlorophyll concentration are observed also in the leaves of Callistephus chinensis 'Strausovo pero Rubinovaya'.

Table 4. The impact of the treatment of plants by Ivin at the chlorophylls concentration in the leaves, $\mathrm{mg} / \mathrm{g}^{-1}$ of raw mass $(\mathrm{n}=4)$

\begin{tabular}{|c|c|c|c|c|c|c|c|c|c|}
\hline \multirow{2}{*}{$\begin{array}{c}\text { The } \\
\text { parameter }\end{array}$} & control & experiment & $\begin{array}{c}\text { \% to } \\
\text { control }\end{array}$ & $\mathrm{t}$ & control & experiment & $\begin{array}{c}\% \text { to } \\
\text { control }\end{array}$ & $\mathrm{t}$ \\
\cline { 2 - 9 } & \multicolumn{7}{|c|}{ 'Viktoria Sharlachovaya' } \\
\hline $\begin{array}{c}\text { Chlorophyll } \\
a\end{array}$ & $1,25 \pm 0,07$ & $1,60 \pm 0,06$ & 128,00 & 3,80 & $1,95 \pm 0,08$ & $2,49 \pm 0,05$ & 127,69 & 5,74 \\
\hline $\begin{array}{c}\text { Chlorophyll } \\
\mathrm{b}\end{array}$ & $0,70 \pm 0,05$ & $0,73 \pm 0,04$ & 104,28 & 0,47 & $0,75 \pm 0,06$ & $0,98 \pm 0,04$ & 130,66 & 3,19 \\
\hline $\begin{array}{c}\text { Chlorophyll } \\
a+\mathrm{b}\end{array}$ & $1,95 \pm 0,08$ & $2,33 \pm 0,10$ & 119,48 & 2,97 & $2,70 \pm 0,07$ & $3,47 \pm 0,11$ & 128,52 & 5,92 \\
\hline $\begin{array}{c}\text { Chlorophyll } \\
a / b\end{array}$ & $1,78 \pm 0,03$ & $2,19 \pm 0,04$ & 123,03 & 8,20 & $2,60 \pm 0,03$ & $2,54 \pm 0,05$ & 97,69 & 1,03 \\
\hline \multicolumn{7}{|c|}{ 'Strausovo pero Rubinovaya' } \\
\hline $\begin{array}{c}\text { Chlorophyll } \\
a\end{array}$ & $1,38 \pm 0,09$ & $1,82 \pm 0,06$ & 131,88 & 4,07 & $1,90 \pm 0,08$ & $2,59 \pm 0,05$ & 136,31 & 7,34 \\
\hline $\begin{array}{c}\text { Chlorophyll } \\
\text { b }\end{array}$ & $0,67 \pm 0,04$ & $0,80 \pm 0,05$ & 119,40 & 2,03 & $0,69 \pm 0,04$ & $0,85 \pm 0,03$ & 123,18 & 3,20 \\
\hline $\begin{array}{c}\text { Chlorophyll } \\
a+b\end{array}$ & $2,05 \pm 0,07$ & $2,63 \pm 0,11$ & 128,29 & 4,46 & $2,68 \pm 0,10$ & $3,44 \pm 0,08$ & 128,35 & 5,93 \\
\hline $\begin{array}{c}\text { Chlorophyll } \\
a / b\end{array}$ & $2,05 \pm 0,03$ & $2,27 \pm 0,04$ & 110,73 & 4,40 & $2,75 \pm 0,05$ & $3,05 \pm 0,04$ & 110,90 & 4,68 \\
\hline
\end{tabular}


Neither the quantity of chlorophyll $a$ nor $b$ in the experiment with the treatment by Ivin after the 3-d spraying is higher, than without it in the leaves of both breeds. The concentration of two forms of the green pigment in the breed 'Viktoria Sharlachovaya' increases almost at the equal level. In the breed 'Strausovo pero Rubinovaya' the profitable action of biostimulant reveals strong at the accumulation of chlorophyll $a$. The ratio of chlorophylls $a / b$ in the leaves of plants of the breed 'Viktoria Sharlachovaya' is almost equal in control and experiment. However, it is valid higher than in the experimental variant in the leaves of 'Strausovo pero Rubinovaya'.

\section{Discussion}

The biostimulants of the cytokinin nature occupy the important place among the physiologically active substances [41]. They participate in the various aspects of the growth and development of the plants, included cell division and differentiation, growth of shoots and roots, apical dominance, involvement of plants and seeds and reaction to the biotic and abiotic stresses [42-44].

According to the data obtained during our investigations, it is established the significant increase of Callistephus chinensis plants height in the result of treatment by the solution of Ivin in relation to the untreated plants in the both breeds 'Viktoria Sharlachovaya' and 'Strausovo pero Rubinovaya'. It should be noted that the literature data about the impact of substances of cytokinin nature at the growth processes of plants are contradictory. According to L.V. Runkova [20] the species specific is revealed. The substances of this group have raised the growth of the height and length of the shoots low in the range of the ornamental flowering plants (dahlia, phlox, carnations). The kartalin slightly enhances the growth of Calendula plants, but kinetin and 6-BAP repress it. Otherwise kinetin increases the height of Helenium sp., but 6-BAP decreases, but the kartalin does not influence at it. M. Grzesik [13] also has not established the essential changes in the development of the rose plants under the influence of benzyl adenine at the concentration of 20$400 \mathrm{mg} / \mathrm{l}$. The stimulation of the growth under the influence of kinetin at the ornamental flowers against the background of the action of the heavy metal was observed by V.P. Bessonova et al. [23]. The number of the side shoots rises at the plants that conformed by the data about the stimulation of branching in Nigella sativa after the influence of the substance of cytokinin nature - kinetin [26]. The activation of the growth and shoot formation in plants treated with Ivin agrees with the enhancing of their dry biomass. Other scientists also mark the increasing of this parameter under the influence of the studying biostimulant. Thus, the increase in phytomass of spinach providing the treatment of the seeds by Ivin was observed by O.I. Ulyanych [45]. The spraying of plants with this preparation contributed to an increase in the mass of root crops [46]. According to the investigations of L.V. Runkova [20] cytokinins (kinetin at a concentration of 20 and $40 \mathrm{mg} / 1,6-B A P 20 \mathrm{mg} / 1$ and kartalin 10, 20 and $40 \mathrm{mg} / \mathrm{l}$ ) increased the weight of ornamental flowering plants (calendula, carnation, dahlia, phlox, helenium) and separate their organs (roots, stems, leaves).

The activation of the growing processes under the impact of N-oxides of pyridine (Ivin) can be ensured due to the change of the chromatin structure and the state of its components [47]. Ivin causes an increase of the level of the chromatin decondensation and intensity of the RNA and protein synthesis. It is identified, that such changes are aimed at the assembly of the proteinsynthesizing system which implements the expression of genetic information by the biosynthesis of enzymes de-novo [48].

We have determined the enhancing of the average area of the leaf blade and total area of the assimilation surface in the treated by Ivin Callistephus chinensis plants in comparison with the untreated, which is more significant in the breed 'Viktoria Sharlachovaya'. The more intensive leaf blade growth spinach under this biostimulant is also pointed out O.I. Ulyanych [45]. S.H. Shah [26] noticed the increase of number of leaves and their square in black cumin under the treatment by kinetin.

It should be pointed out that formation of the larger number of shoots at the plants of both breeds of callistephus in comparison with untreated specimens is the extreme importance to the design of additional flowers. The data about stimulation of the blooming by the substances of 
cytokinin nature is presented in the literature. N. Nambiar et al. [41] has established that under the impact of cytokinin (6-BAP) increases the percentage of creating inflorescences of orchid Dendrobium sp. It is reported about the success in regulating the formation of inflorescences under the treatment of BAP in orchids by M.G. Blanchard and E.S. Runkle [49]. This is consistent with our results of the influence of Ivin on the number of the inflorescences on the treated plants of Callistephus chinensis. However the above mentioned authors have noted that the use of BAP does not essentially influence at the flowers size while in our experiment not big, but statistical valid increasing diameter of inflorescences Callistephus chinensis under the impact of Ivin in comparison with untreated plants was determined. Cytokinins are regarded as critical physiological signal that forces the flowering process [50]. Their level has increased in the apical meristems during pass to the blossom and development of flower in Arabidopsis thaliana L. [51].

The positive impact of Ivin to the area of leaf blade may be the reason of enhancing the flowering intensity. A number of scientists point out the connection of these two parameters. As recently as K.F. Wentrel [52] has shown in the experiment that the development of determine area of leaf surface during the initial formation of flowers has a particularly importance. Permanent leaf removal may also inhibit the late stages of flowers formation, that's why blooming does not begin but the buds untimely fell as it was established in experiments with grape. It is proved also by other authors. Thus, it was found that not only the number of inflorescences is a direct function of area of leaf blade, but also the speed of move to blooming [53]. The removal of leaves in lily of breed 'Croft' with inducing the distortion of the assimilation system enhances the aborting of flowers [54]. The initiation of flowering depends from provision with assimilators, first a wall with carbohydrates [55]. The increasing of leaves area provides their bigger synthesis. Our data confirms the results obtained by other authors on the connection between the activation of the development of the assimilation apparatus and the formation of flowers.

It is found out the increase of the concentration of green pigments in the leaves of the plants treated by Ivin in comparison with untreated. The character of enhancement of the chlorophylls concentration depends on the time of conducting the plants treatment. The amount of chlorophyll $a$ rises under the influence of the biostimulant after the spraying plants at the seedling stage as well as in the phase of bud formation, otherwise the chlorophyll $b$ increases only during the treatment in phase of bud formation as in the breed 'Viktoria Sharlachovaya' almost equally with chlorophyll a both in breed 'Strausovo pero Rubinivoya' however in a less degree than chlorophyll a. It is explained that the ratio of chlorophylls rises in both breeds during treatment of plants in the seedling stage, but in the period of bud formation $a / b$ grows up only in the case with breed 'Strausovo pero Rubinovaya'. According to the research of M.N. Zhizhina and A.V. Omelchenko [32] Ivin provides the enhancement of the green pigment concentration at the salinity background. However the positive action of Ivin reveals the more on the accumulation of chlorophyll $b$ in comparison with chlorophyll $a$ that contradicted to our results. The sum of chlorophylls $a+b$ increases under the influencing of treatment with the biostimulant. This may be one of the factors of the effect of Ivin on plant growth processes, because a number of scientists found out the close relationship between growth, production of plants and concentration of chlorophylls in the leaves [56-58].

\section{Conclusions}

Our research shows that:

1. The treatment of Callistephus chinensis plants after sowing seedlings in the phase of active growth and bud formation by the solution of Ivin leads to the intensification of the growth processes in comparison with untreated samples that is revealed in increasing the vegetative mass, the number of side shoots, leaves, inflorescences, in a less degree of the diameter of the latter and the height of shrub. The evident difference in the stimulated action of Ivin at the studying parameters is not determined except the total assimilation surface that grows up significantly in the plants of breed 'Viktoria Sharlachovaya'. 
2. The spraying plants by Ivin increases the concentration of chlorophyll in the leaves of two investigated breeds due to chlorophyll $a$.

3. The increase of the both forms of green pigments was noticed after treatment the plants in the phase of bud formation. In this case we have remarked the breed specific in the reaction of plants. In the leaves of the breed 'Viktoria Sharlachovaya' the level of chlorophylls $a$ and $b$ raises almost equally, however in the breed 'Strausovo pero Rubinovaya' chlorophyll $a$ rises vital.

4. We recommend to implement the preparation of cytokinin type (Ivin) for the stimulation and intensity of blooming the plants Callistephus chinensis which grown in beds in the urban territories. The treatment is suggested to conduct by the spraying of plants in the seedling stage, during the active growth of the plants and in the start of budding in the concentrations which pointed out by producer for other species.

\section{Conflict of Interests}

The authors declare that there is no conflict of interest.

\section{Acknowledgements}

The authors appreciate Philonenko O.E. for help during the growing of the plants of china aster.

\section{References}

[1] S. Batterman, R. Ganguly \& P. Harbin, High resolution spatial and temporal mapping of traffic-related air pollutants, International Journal of Environmental Research and Public Health. 12(4) (2015). 3646-3666. DOI:10.3390/ijerph120403646.

[2] D.J. Nowak, E.C. D.E. Crane, J.C. Stevens, Air pollution removal by urban trees and shrubs in the United States, Urban Forestry \& Urban Greening. 4 (2006) 115-123. DOI:10.1016/j.ufug.2006.01.007.

[3] D.J. Nowak, S. Hirabayashi, M. Doyle, M. McGovern, J. Pasher, Air pollution removal by urban forests in Canada and its effect on air quality and human health, Urban Forestry \& Urban Greening. 29 (2018) 40-48. DOI: 10.1016/j.ufug.2017.10.019.

[4] S. Cen Biological monitoring of air pollutants and its influence on human beings open, Biomed Eng J. 9 (2015) 219-223. DOI: 10.2174/1874120701509010219.

[5] N. Belousova, N. Lunina, The modern tendency of the ornamental gardening of the Belorussian cities, Science and Innovation. 5 (2016). 7-9.

[6] L.P. Gievaya, A.L. Kalmykova. The ornamental gardening M.A. Gorkogiy PKiO in Saratov city Landscape Architecture Bulletin. 8 (2016) 27-29.

[7] E.V. Semenkova, On the question of the systematical approach to the flowering gardening in the city, Forestry Bulletin. 5 (2015) 23-27.

[8] O.S. Zalivskaya, Je.V. Drochneva, The flowering gardening of Arkhangelsk city, the International student issue. 2 (2016) 187.

[9] G.A. Potaev, A.D. Nikonchik, The ways of reconstruction the formed parks territories in the big cities, Architecture: the issue of scientific proceedings. 1 (2008) 87-90.

[10] O.E. Ivanchenko, V.P. Bessonova, N.V. Kapelyush, Concentration of heavy metals in leaves of woody plants perks of Dnepropetrovsk. Visnyk of Lviv University. Biological series. 72 (2016) 82-92.

[11] J.G. Atherton, G.P. Harris, Effects of chilling on the formation of secondary growing-centres in flowers on the glasshouse carnation, Sci. hort. 13(4) (1980) 371-376.

[12] S.-T. Chang, W.-S. Chen, M. Koshioka, L.N. Mander, K.-L. Huang \& B.-S. Du, Gibberellins in relation to flowering in Polianthes tuberosa, Physiologia Plantarum, 112(3) (2001). 429432. DOI: 10.1034/j.1399-3054.2001.1120317.x.

[13] M. Grzesik Mozliwośc stosowania regylatorow wzrostu w produkciji roz, Ogrodnictwo. 24(8) (1987) 19-20. 
[14] O.E. Hanbabaeva, E.A. Kozlova, A.E. Macneva, The effect of treatment with gibberellic acids on the growth and development of the flowering annual culture, The International TechnicalEconomic Journal. 5 (2015) 100-106.

[15] G. Hanks, A. Rees Substitution of tulip cold requirement by gibberellins, Intern. Hort. Congr. Abstr. Collect. 2 (1982) 1708.

[16] A. Pobudkiewicz, The influence of growth retardants and cytokinins on flowering of ornamental plants, Acta Agrobotanica. 61 (1) (2008) 137-141. DOI: https://doi.org/10.5586/aa.2008.018.

[17] A.V. Roberts, P.S. Blake, R. Lewis, J.M. Taylor \& D.I. Dunstan, The Effect of Gibberellins on Flowering in Roses, Journal of Plant Growth Regulation. 18(3) (1999) 113-119. DOI:10.1007/p100007058.

[18] L.V. Rounkova, Gibberellin and retardants influence on some ornamental plants and a level of their native growth substances, Acta Hortic. 91 (1979) 437-448. DOI: 10.17660/ActaHortic.1979.91.53.

[19] L.V. Runkova, The effect of growth stimulators on the ornamental plants, Nauka, Moscow, 1984.

[20] L.V. Runkova, The effect of cytokinins on the ornamental plants, Biostimulants and inhibitors of the plants growth processes, (1988) 110-122.

[21] P.A. Tomas, G.D. Coorts, J.E. Preece, The effect of phtalamides AC 99524, AC 94377 and gibberellic acid $\left(\mathrm{GA}_{3}\right)$ on flowering of cyclamen persicum $\mathrm{F}_{1}$ hybrids, Hort. Science. 16(3) (1981) 409.

[22] J. Tonecki, Effect of short photoperiod and growth regulators on growth, flowering and tuberization of Begonia $\times$ tuberhybrida, Acta hortic. Wageningen. 177(1) (1986) 147-156.

[23] V.P. Bessonova, I.I. Lyzhenko, O.F. Mikhailov, O.N. Kulaeva, Effect of cytokinin of plant growth and chlorophyll content under conditions of atmospheric pollution. Plant physiology. 31(6) (1984) 1149-1153.

[24] V.P. Bessonova, The effect of polystimulin K on the photosynthetic apparatus of sweet pea plants, which was cultivated under the excess of iron, Manganese and chrome, Physiology and biochemistry of cultivated plants. 23(2) (1991). 158-163.

[25] M. Kamínek, T. Vaněk, A. Kalendová-Kulasová, J. Pilar̆, The effect of two cytokinins on production of stem cuttings by stock plants of Euphorbia pulcherrima Willd. and Gerbera jamesonii Hook, Sc. hortic. 33 (3/4) (1987) 281-289.

[26] S.H. Shah, The effect of the spraying with kinetin on the growth and production of Nigella sativa plants, Plant physiology. 54(5) (2007) 790-793.

[27] A. Trivellini, G. Cocetta, P. Vernieri, A. Mensuali-Sodi, \& A. Ferrante, Effect of cytokinins on delaying petunia flower senescence: a transcriptome study approach. Plant Molecular Biology, 87(1-2) (2015) 169-180. DOI:10.1007/s11103-014-0268-8.

[28] E.Yu. Bakhtenko, Yu.A. Suslov, B.P. Kurapov, T.V. Khurshkainen, Comparative study of the efficiencies of plant growth regulators for fiber flax, Agrochemistry. 8 (2011) 37-43.

[29] Y. Sajjad, M.J. Jaskani, M. Asif, M. Qasim, Application of plant growth regulators in ornamental plants: a review, Pak. J. Agri. Sci. 54(2) (2017) 327-333. DOI: 10.21162/PAKJAS/17.3659.

[30] E.P. Priymak, Effect of 24-epibrasonolid on the growth processes of some ornamental flowering plants in the conditions of the environmental pollution with automobile fumes, Problems of bioindications and ecology. 12(1) (2007) 80-99.

[31] V.A. Vostokova, L.T. Suhenko, M.A. Egorov. The effect of the plants biological ctive substances on the development of hothouse plants, Issue of the publication of the multidisciplinary scientific journal "Archivarius" on the materials of the XXst International scientifically-practical conference "The Science in the modern world" (Kiev), Multydiciplinary scientific journal "Archivarius”, Kiev, 2017. 5-9. 
[32] M.N. Zhizhina, A.V. Omelchenko, Influence of regulators of growth on some structurally functional indicators of activity of the photosynthetic salinization, The scientific proceedings of V.I. Vernadsky Crimerian federal university. Biology. Chemistry. 3 (69) (2017) 82-90.

[33] M.N. Zhizhina, S.N. Kabuzenko, The effect of the biological active substances on the miotic aactivity of the root meristem cells of corn and barley plants in the conditions of salinisation stress, The Scientific Proceedings of V.I. Vernadskiy Tavricheskiy National University. Biology. Chemistry. 19 (58) (2006) 80-85.

[34] V.P. Bessonova, O.E. Ivanchenko, E.P. Priymak, The effect of polystimulin K on flowering quality in ornamental flowering plants in the polluted environment, Ukr. Botan. Journ. 63(4) (2006) 541-550.

[35] V.P. Bessonova, The effect of heavy metals and polystimulin $\mathrm{K}$ on the antioxidant system the cells of sweet pea leaves, Physiology and biochemistry of cultivated plants. 24(2) (1992). $137-153$.

[36] O.E. Ivanchenko, The effect of polystimulin $\mathrm{K}$ on the growth of vegetative organs the ornamental flowering plants at the bachground of the environmental pollution with iron and chrome substances, Problems of bioindications and ecology. 9(2) (2004) 10-22.

[37] V.M. Trojan, V.K. Javors'ka, S.P. Ponomarenko et al., The theoretical approachs of the application of the groWth regulator 2.6-dimethylpyridin-N-oxide in the crop research, Physiology and biochemistry of cultivated plants. 23(5) (1991) 468-4473.

[38] The re-edition of the official Supplement to the List of pesticides and agrochemicals acceptable for using in Ukraine as of 2017, in line with State Service of Ukraine to Food Safety and Consumer Protection (the letter from 02.06.2017 № 602-123-10/5036), Univest Media, Kiev, 2017.

[39] R.M. Klejn, T.D. Klejn, Plant research methods, Kolos, Moscow, 1974.

[40] V.F. Gavrilenko, T.V. Zhigalova. The big practicum on photosyntsesis, The publisher center "Academia", Moscow, 2003.

[41] N. Nambiar, T.C. Siang, M. Mahmood, Effect of 6-Benzylaminopurine on flowering of a Dendrobium orchid, Australian Journal of Crop Science. 6(2) (2012) 225-231.

[42] P.E. Jameson, J. Song, Cytokinin: a key driver of seed yield, Journal of Experimental Botany. 67(3) (2016) 593-606. DOI:10.1093/jxb/erv461.

[43] M. Mohd, A.K. Taqi, M. Firoz, Cytokinins, a classical multifaceted hormone in plant system, Journal of Stress Physiology \& Biochemistry. 7(4) (2011) 347-368.

[44] T. Werner, V. Motyka, M. Strnad and T. Schmülling, Regulation of Plant Growth by Cytokinin, Proceedings of the National Academy of Sciences of the United States of America. 98(18) (2001) 10487-10492. DOI: https://doi.org/10.1073/pnas.171304098.

[45] O.I. Ulyanych, Production of spinach depending on the treatment of seeds with growth regulators, The Bulletin of Kharkiv National Agrarian University. Series Biology. 2 (2009) 94-97.

[46] I.V. Dydiv, The effect of Ivin and emistim C on the production of parsnip in the conditions of West Forrest-Steppe zone of Ukraine, Vegetable and melon growing. 54 (2008) 156-162.

[47] A.V. Kolisnyk, M.V. Draga, S.A. Shumik, M.M. Musienko, Effect of N-oxydes of pyridins (Ivin and triman) and kinetin on the nitrogen metabolism of wheat, Physiology and biochemistry of cultivated plants. 32(5) (2000) 394-400.

[48] N.L. Kljachko, L.A. Jakovleva, F.M. Shakirova, The effect of cytokinin on the protein synthesis in the isolated pumpkin cotyledon, Plant growth and development regulators, Nauka, Moscow (1981) 29-30.

[49] M.G. Blanchard, E.S. Runkle, Benzyladenine promotes flowering in Doritaenopsis and Phalaenopsis orchids, J Plant Growth Regul. 27 (2008) 141-150. DOI:10.1007/s00344-0089040-0.

[50] F. Bonhomme, B. Kurz, S. Melzer, G. Bernier \& A. Jacqmard, Cytokinin and gibberellin activate $\operatorname{SaMADS} A$, a gene apparently involved in regulation of the floral transition in Sinapis alba, Plant J. 24. (2000) 103-111. DOI: 10.1046/j.1365-313x.2000.0089.x. 
[51] L. Corbesier, E. Prinsen, A. Jacqmard, P. Lejeune, H.V. Onckelen, C. Périlleux, G. Bernier, Cytokinin levels in leaves, leaf exudate and shoot apical meristem of Arabidopsis thaliana during floral transition, J Exp Bot. 54(392) (2003) 2511-2517. DOI: 10.1093/jxb/erg276.

[52] K.F. Wentrel Habitus-Anderung der walabaaume durch duftverlinigung, Forstarchiv. 41 (1971) 165-172.

[53] A. Ramina, W.P. Hackett, R.M. Sachs, Flowering in Bougainvillea: a Function of Assimilate Supply and Nutrient Diversion, Plant Physiol. 64(5) (1979) 810-813.

[54] J.W. Mastalke, Changes of axillary meristem localization in relation to flowering, Proc. Am. Soc. Hortic Sci. 502 (1956) 87.

[55] T.N. Kantanistova, T.V. Bavrina, A.P. Aksenova, S.A. Goljanovskaja, The action of glucose at the morphogenesis of shooy calluses of photoperiodical neutral tobacco Trapesond, Plant physiology, 19 (1972) 89-97.

[56] Yu.E. Andrianova, I.A. Tarchevsky, Chlorophyll and plant productivity, Moscow, Nauka, 2000.

[57] V.P. Karpenko, S.S. Shutko, Chlorophyll concentration and photosynthetic productivity in soriz while applying of Pik 75 WG herbicide and Regoplant plant growth regulator, Journal of Uman NUH. 93(1) (2018) 23-32. DOI: 10.31395/2415-8240-2018-93-1-23-32.

[58] G.O. Priadkina, O.V. Maslyukivska, O.O. Stasik, V.P. Oksem, Relationships between leaves and canopy chlorophyll concentrations at grain filling and productivity of winter wheat, Plant physiology and genetics. 47(2) (2015) 167-174. 